DOI: $10.17805 /$ ggz.2019.1.3

\title{
Социальная справедливость: современная история идеи
}

\author{
Г. Ю. Канарш \\ Институт философии РАН
}

Статья посвящена анализу идеи справедливости в западной политической философии эпохи модерна. Автор, отталкиваясь от своих более ранних публикаџий, прослеживает историю конщепџии справедливости в «великих идеологиях» (либерализм, консерватизм, марксизм), а также достаточно подробно рассматривает основные подходы к пониманию справедливости в современной политической теории. Задача автора - не только анализ тех или иных позиций в отношении проблемы справедливости, но и поиск наиболее удовлетворительной ее концепџии. В качестве таковой названа прежде всего концепиия «функциональных возможностей» современных исследователей Амартии Сена и Марты Нуссбаум.

Ключевые слова: сочиальная справедливость; «великие идеологии»; либерализм; консерватизм; марксизм; деонтологический либерализм; меритократия; либертаризм; коммунитаризм; социал-демократия; концепџия «функииональных возможностей»

\section{Social Justice: Modern History of the Idea}

\author{
G. Yu. Kanarsh \\ Institute of Philosophy, Russian Academy of Sciences
}

The article analyzes the idea of justice in Western political philosophy. Drawing on his earlier publications, the author traces the history of the concept of justice in the "great ideologies" (liberalism, conservatism, and Marxism), and also examines in detail the main approaches to the understanding of justice in modern political theory. The author's task is not only to analyze certain attitudes to the problem of justice, but also to find the most satisfactory conception. As such, the conception of "functional capabilities" proposed by contemporary researchers Amartya Sen and Martha Nussbaum is mentioned first of all.

Keywords: social justice; "great ideologies"; liberalism; conservatism; Marxism; deontological liberalism; meritocracy; libertarianism; communitarianism; social democracy; conception of "functional capabilities"

\section{ВВЕДЕНИЕ}

Справедливость - важнейшая категория социальной и политической философии и этики. В политике и социальной философии справедливость правильное соотношение базисных политических ценностей свободы и блага, свободы и равенства. Рассуждения о справедливости занимали значительное 
место в трудах античных мыслителей - Платона и Аристотеля. Античносредневековая традиция осмысления справедливости в целом была связана с понятием блага. Противостоящая ей новоевропейская концепция связывает справедливость уже не с благом, а с правом, в основе чего - фундаментальные идейно-политические трансформации, переход от «этики блага» к индивидуалистической «этике права» (Штраус, 2000: 278). В современной политической философии представлен весь спектр философских представлений о справедливости - как правовых, так и телеологических. Исходная точка современного дискурса справедливости - выход в свет книги американского философа Джона Ролза «Теория справедливости» (Rawls, 1971). Многочисленные концепции, возникшие в западной политической философии в 1970-е, 1980-е и 1990-е гг. — во многом результат той или иной реакции на работы Ролза.

В нашей более ранней статье (см.: Канарш, 2018; см. также: Канарш, 2011) мы подробно рассмотрели основные этапы развития концепции справедливости в истории политической философии. В настоящей работе мы проанализируем особенности данной концепции в «великих идеологиях» современности (либерализм, консерватизм, марксизм), а также более подробно изучим ключевые подходы к пониманию категории справедливости в современной нормативной политической теории.

\section{КОНЦЕПЦИЯ СПРАВЕДЛИВОСТИ В «ВЕЛИКИХ ИДЕОЛОГИЯХ»}

Значимые альтернативы либеральной идеологии, выдвинувшие идею блага (в том или ином виде) вместо принципов права, формируются уже непосредственно с окончанием эпохи Просвещения - в начале и в течение XIX столетия. Это, прежде всего, консерватизм и марксизм, в рамках которых формируются собственные представления о справедливости. В самой же либеральной политической философии в XIX в. влиятельным направлением становится утилитаризм, основы которого были заложены в трудах английских философов И. Бентама и Дж. Ст. Милля.

Основную логику консервативной мысли по отношению к свободе и справедливости раскрыл в своей известной работе «Консервативная мысль» немецкий социолог знания К. Манхейм. Он пишет о взаимодополнительности концепций свободы и равенства в политической доктрине Просвещения. Свобода в этой доктрине означает возможность для индивида поступать согласно собственной воле и пользоваться правами человека. Свобода в этом случае ограничена лишь свободой других людей. Равенство таким образом оказывается естественным дополнением просвещенческого понимания свободы. Однако, как указывает Манхейм, новизна и оригинальность консервативной мысли заключалась в том, что она — в противоположность идеологии Просвещения - выработала собственную концепцию свободы, сосредоточившись при этом на критике не собственно данного понятия [свободы], но на более глубоко лежащей концепции равенства. Как пишет Манхейм, «политическая необходимость заставила консерваторов выработать собственное 
понимание свободы, отличное от либерального. Они выработали нечто, что можно было бы назвать качественной идеей свободы в отличие от ее революционно-эгалитарной концепции. < .. > У тверждалось, что люди принципиально неравны, неравны талантом и способностями, неравны в самом своем существе. Свобода может, таким образом, основываться исключительно на способности каждого индивидуума к развитию без препятствий со стороны других согласно праву и обязанностям собственной личности» (Манхейм, 1994: 604; курсив источника. - Г. К.). Таким образом, для консерваторов, в отличие от либералов, свобода приобретает не количественный, а качественный характер, и естественным ограничением свободы становится не такая же свобода других людей, но естественный закон развития индивидуума, что в значительной мере напоминает традицию Аристотеля. Однако, как показывает Манхейм, утвердив данное понимание свободы и равенства, консервативная мысль вскоре осознала опасность возможности определенной анархии, которую нес с собой данный индивидуалистический субъективизм. Свобода, центрированная на индивиде, даже имея такой, специфический качественный характер, могла тем не менее представлять угрозу для общественного целого. Поэтому следующим шагом, который осуществили консерваторы в сфере политической мысли, был перенос основного носителя свободы с индивида на органические коллективы - сословия: «С тех пор сословия стали носителями внутреннего принципа развития, в неограниченной реализации которого состоит свобода...» (там же: 605). Одновременно трансформируется само нормативное содержание данного понятия: свобода отныне означает привилегии различных сословий (в соответствии с феодальным порядком), «а качественный и неэгалитарный привкус, заключенный в средневековой концепции, вновь оживает» (там же). Таким образом, консервативная мысль, не отказавшись от самих концепций свободы и равенства, радикальным образом трансформировала их смысл: фактически произошел возврат к античносредневековой концепции общего блага и справедливости, которые принадлежат миру органических сообществ (античный полис, средневековые корпорации). Это - холистская интерпретация справедливости, которая, согласно Манхейму, находит свое логическое завершение в понятии нации как органического сообщества. В конечном счете даже не сословия становятся главными носителями свободы, но наиболее крупные сообщества - нации: «Только государство, развиваясь свободно по своим собственным законам развития, - свободно. Индивидуум ограничен и может быть полезен только в границах этих более широких общностей» (там же: 606). Консервативная мысль, основные идеи которой впервые были сформулированы в трудах англичанина Э. Берка и франко-итальянца Ж. де Местра (Берк, 1993; Местр де, 1997), уже с начала XIX в. стала влиятельным направлением европейской политической философии, а сам консерватизм рассматривается как одна из трех великих идеологий Современности. И несмотря на то, что в современных условиях уже нет возможности говорить о привилегиях отдельных сословий, как и о тотализирующем воздействии органического целого (нации), тем не менее, в той или иной форме консервативные идеи качественного понимания 
свободы, равенства и справедливости продолжают существовать и определять влиятельные направления современного политического дискурса.

Говоря о развитии концепции справедливости в XIX столетии, нельзя обойти такое влиятельное направление политической мысли, как утилитаризм. У его истоков стоят два выдающихся мыслителя - И. Бентам и Дж. Ст. Милль (Бентам, 1998; Милль, 2013). Особенность утилитаризма, как и других телеологических доктрин, заключается в том, что он выводит справедливость из более широкого нормативного принципа - пользы или блага. Как отмечает отечественный исследователь проблемы справедливости Б. Н. Кашников, «польза венчает собой триаду основных моральных принципов классического утилитаризма: польза, счастье и гедонизм (удовольствия)» (Кашников, 2004: 56). При этом счастье составляет основное содержание принципа полезности (достижение максимального счастья для максимального количества людей), а удовольствие - то, что составляет содержание счастья. При этом утилитаризм, в отличие, например, от консерватизма, является индивидуалистической и эгалитарной доктриной, поэтому еще одним важнейшим его принципом выступает равенство (каждый должен иметь равную возможность для максимизации своего счастья или совокупности удовольствий). Таким образом, утилитаризм рассматривает как соответствующее справедливости то общественное устройство, которое максимизирует счастье для максимального количества индивидов. И таковым устройством является, согласно утилитарной доктрине, рыночная экономика с парламентским политическим устройством. При этом, если говорить о более частных аспектах концепции справедливости утилитаризма, то он поддерживает, во-первых, справедливое распределение как ведущее к наибольшему счастью наибольшего количества индивидов (распределительная справедливость); свободный рыночный обмен (меновая справедливость); и такой вариант воздающей справедливости, который вел бы не просто к наказанию преступника, но к его исправлению, и таким образом, способствовал бы достижению счастья как общества в целом, так и самого преступника (там же: 57). При всем этом, классический утилитаризм как концепция справедливости на всем протяжении своей истории подвергается значительной критике. Основа этой критики - в тех значительных опасностях для общества и в особенности прав человека, которые несет с собой утилитаристская доктрина. Эта опасность со времен Бентама заключается в том, что утилитаризм потенциально несет в себе возможность пожертвовать правами и интересами индивида (и даже целых групп) ради достижения максимального благосостояния целого. Кроме того, концепция классического утилитаризма (особенно в ее бентамовском варианте) заключала в себе возможность манипулирования общественным сознанием со стороны правящего класса, поскольку не проводилось какоголибо различия между разными видами удовольствия, а значит всегда существовала возможность превращение больших масс людей в подобие животных, которые предпочитают получение все новых и новых удовольствий вместо собственно человеческого образа жизни. Существенной коррекции утилитаристская доктрина была подвергнута в работах последователя и од- 
новременно критика Бентама Дж. Ст. Милля, который, во-первых, строго разграничил «животные» и возвышенные удовольствия, указав на то, что именно достижение вторых должно представлять собой подлинную цель утилитаризма; а во-вторых, стал основателем т. н. «утилитаризма правил» (в противоположность бентамовскому «утилитаризму действия»), в соответствии с которым стремление к максимальной полезности ни в коем случае не может пренебрегать важнейшими интересами и правами человека. Не случайно поэтому именно фигура Милля стоит у истоков современной концепции социальной (распределительной) справедливости, а также парламентской демократии, как строя, наилучшим образом охраняющего индивидуальную свободу (Алексеева, 2000; Кашников, 2004; Прокофьев, 2010). Утилитаризм как политическая философия и концепция справедливости оказал значительное влияние на развитие современной политической мысли, став, в частности, идеологической основой государства благосостояния. Правда, само понятие пользы подверглось значительной трансформации: из принципа максимизации удовольствий польза превратилась в принцип максимизации индивидуальных желаний или предпочтений, благодаря чему стало возможным операционализировать данный принцип (подсчитать, как и каким образом возможно удовлетворение субъективных предпочтений). Значительные философские труды, развивающие идеи утилитаризма, появлялись и в последней трети ХХ в., когда, казалось бы, утилитаризм был подвергнут сокрушительной критике в работах Дж. Ролза. В целом по сегодняшний день утилитаризм остается влиятельной политико-философской концепцией, хотя и подвергается во многих работах по проблеме справедливости обоснованной критике.

Важнейшим направлением в развитии концепции справедливости в «век идеологий» стало формирование левой, и прежде всего марксистской мысли. Марксизм, также как консерватизм и либерализм, оказал и продолжает оказывать огромное влияние на современную политическую мысль. Подобно консерватизму, марксизм выступил в качестве критического течения, подвергнув уничтожающей критике многие основания «проекта Современности». И несмотря на то, что консерватизм традиционно рассматривается как «правая» идеология, а марксизм как «левая», очень многие мысли в этих двух течениях оказывается схожими. Прежде всего, марксизм как социальное и политическое учение не говорит явно и прямо о справедливости. Справедливость, с точки зрения К. Маркса, - надстроечное понятие, содержание которого отражает либо господствующие социально-экономические отношения, либо определяется революционным дискурсом. Не случайно поэтому среди исследователей возникло двойственное отношение к самому проекту коммунистического общества: одни видели это общество как стоящее «по ту сторону» справедливости (некоторые западные авторы), другие же рассматривали коммунизм как высшее воплощение справедливости (советские авторы). В целом же современные российские исследователи говорят о возможности вычленить в трудах К. Маркса и Ф. Энгельса собственно коммунистическую концепцию справедливости, которая представляет собой «идеал об- 
щества свободного неотчужденного труда, где отсутствует эксплуатация, имеет место бурное развитие производительных сил и возвышение потребностей» (Кашников, 2004: 141-142). Однако в целом позитивная концепция справедливости в трудах Маркса не получила значительного развития, основные аспекты справедливого общества в трудах основателей марксистской мысли раскрываются скорее через критику капитализма. По мнению Б. Н. Кашникова, эту критику можно разделить на три основных направления:

1) критика буржуазного общества с точки зрения развития производительных сил и удовлетворения потребностей;

2) критика с точки зрения концепции эксплуатации;

3) перфекционистская критика с точки зрения концепции отчуждения (там же:136; см. также: Кимлика, 2010: 232-259).

По первому пункту основная претензия Маркса к современному ему буржуазному обществу состоит в том, что в нем, во-первых, начинает тормозиться развитие производительных сил (из-за противоречия с имеющимися производственными отношениями), а во-вторых, в том, что сам характер потребностей, соответствующих данному типу общества, уже не способствует развитию нового типа экономических отношений. В новом, коммунистическом обществе, основанном на социализации средств производства, меняется, согласно Марксу, сам характер человеческих потребностей (происходит их возвышение), что в итоге способствует и развитию производительных сил (их бесконечному совершенствованию). Таким образом, коммунистическое общество оказывается лучше (совершеннее) общества буржуазного, поскольку оно наилучшим образом удовлетворяет потребности людей. Второй аргумент (критика с точки зрения концепции эксплуатации) носит кантианский характер. Основная претензия Маркса к буржуазному обществу с этих позиций заключается в том, что капиталист эксплуатирует рабочего самым жестоким образом, присваивая себе произведенный рабочим прибавочный продукт. Характер этой эксплуатации таков, что «рабочего не просто используют как средство, его именно эксплуатируют» (Кашников, 2004: 148). На это указывают три признака прибавочного труда:

1) принудительный труд (рабочий не может обойтись без капиталистического найма);

2) неоплаченный труд (капиталист забирает себе стоимость, произведенную рабочим);

3) труд, приносящий вред самому рабочему, поскольку ввергает его в состояние отчуждения.

Поэтому «все это вместе взятое превращает наемный труд в разновидность рабства» (там же: 149). Удел рабочего в буржуазном обществе - вечно работать даром в пользу другого лица. Наконец, перфекционистский аргумент от концепции отчуждения заключается в том, что работа на капиталиста приводит к физическому, духовному и нравственному оскудению рабочего, к деформации, а в конечном счете и деградации его личности. При этом в работах Маркса насчитывается не одна, а целый ряд различных форм отчужде- 
ния: отчуждение процесса труда, отчуждение условий труда, отчуждение результатов труда, отчуждение сознания (формирование соответствующих идеологических форм), отчуждение общественной власти, отчуждение человека от человека, отчуждение потребностей. Но самая главная форма отчуждения, которая венчает все предыдущие и является главным злом для человека - это отчуждение от собственной человеческой сущности. Поэтому, в соответствии с марксовой концепцией справедливости «общество должно быть организовано таким образом, чтобы обеспечить развитие человеческого совершенства и предотвратить его деградацию. <..> Неотчужденной формой жизни является коммунизм с его общественной собственностью на средства производства, для которого всестороннее развитие человеческой природы становится уже не косвенным и случайным последствием, но самоцелью» (там же: 152-153). Таким образом, марксова концепция справедливости, проистекающая из его критики капитализма, на свой лад говорит нам об определенном варианте человеческого блага, которое (в случае перфекционистского аргумента) явным образом восходит к античной (аристотелевской) традиции. Подобно Аристотелю Маркс говорит о необходимости создавать условия для развития человеческой личности - тезис, который позже (уже в наше время) будет позаимствован у Маркса социал-демократами и - в поле политической теории - аристотелианцами социал-демократического толка (прежде всего, М. Нуссбаум). Несмотря на очевидный кризис левого движения и левой идеологии в мире (вместе с распадом СССР) концепция справедливости Маркса остается по-прежнему весьма влиятельной, а ее положения лежат в фундаменте целого ряда современных социально-этических концепций.

\section{СОВРЕМЕННЫЕ ДИСКУССИИ О СПРАВЕДЛИВОСТИ}

Начало современных дискуссий о справедливости традиционно связывают с выходом знаменитой книги американского философа Дж. Ролза «Теория справедливости» (Ролз, 1995; Ролз, 2010). Как отмечается в многочисленных работах, посвященных теории Ролза, она в первую очередь была направлена против позитивизма и утилитаризма, господствовавших на протяжении десятилетий в англо-американской социальной мысли. Позитивизму Ролз противопоставил нормативную политическую теорию, утилитаризму концепцию, основанную на приоритете права, а не блага. В качестве нормативной теории Ролз отвергает утилитаризм на следующих основаниях: вопервых, утилитаризм в своем стремлении к общественной пользе не принимает во внимание, каким образом распределено в обществе благо и зло. В этом отношении принцип максимизации общей полезности может стать оправданием для рабовладельческого общества (Кашников, 2004: 152-153). Во-вторых, утилитаризм не проводит достаточного различия между индивидами. Выбор той или иной меры полезности, согласно философамутилитаристам, должен осуществлять беспристрастный законодатель, но это потенциально может привести к тому, что определенные аспекты блага будут не учтены (или предпочтение будет оказано другим аспектам) в процессе рационального выбора. В-третьих, утилитаризм не учитывает качественную 
природу распределяемых благ. В этом отношении может оказаться так, что выбор может быть сделан в пользу антиобщественных «благ» (например, получения удовольствия садистом), вместо увеличения (максимизации) благ, которые действительно приносят пользу обществу. В итоге Ролз формулирует три принципа справедливости (принцип равных максимальных свобод, принцип равенства возможностей и принцип дифференциации), главным из которых является именно принцип равных максимальных свобод как очерчивающий пространство справедливости в сообществе, которое должно ограничивать любые соображения блага.

Гораздо менее, чем полемика Ролза с утилитаризмом, известна его дискуссия с представителями меритократической концепции справедливости. Задачей, не менее важной, чем создать теорию справедливости, противоположную утилитаризму, являлась попытка американского философа найти достойную альтернативу концепциям меритократии, ставшим заметным явлением в западной (прежде всего, американской) политической мысли 19601970-х гг. Важным текстом, с идеями которого полемизирует Ролз, является книга американского социолога М. Янга «Возвышение меритократии» (Young, 1961). В этой книге, впервые увидевшей свет в 1958 г., составленной в жанре антиутопии, говорится о фундаментальных трансформациях британского общества на рубеже XX-XXI вв. Британия, согласно сюжету книги, начала терять свои конкурентные преимущества в мире прежде всего по причине устаревшей и неэффективной социальной структуры, основанной на традиционном владении ресурсами. Увеличить конкурентные преимущества страны, таким образом, оказывается возможным только через изменение характера социальной стратификации, в основу которой должен быть положен новый принцип - принцип заслуг. Формулой создания нового господствующего класса, основанного на естественных преимуществах (обладание талантами, высоким уровнем интеллекта) становится формула I + E = M (интеллект плюс усилия равно заслуги). Таким образом, данный принцип, начиная с системы образования, постепенно проникает во все общественные сферы, формируя таким образом новую элиту страны. В свою очередь, это означает, что наиболее талантливые люди из всех слоев общества становятся членами нового правящего класса, а низшие классы, напротив, формируются из тех, кто является наименее одаренным. В результате, согласно концепции меритократии, формируется справедливое и социально эффективное общество, которое легитимизируется благодаря естественному наличию (или отсутствию) талантов. Однако, как показывает Янг, справедливость такого общества является более чем сомнительной, и в результате в далеком 2033 году низшие классы при определенной поддержке со стороны некоторых представителей правящего класса поднимают восстание, в результате которого меритократическое общество упраздняется.

Как показывают некоторые исследователи (Кроль, б/д: Электронный ресурс), концепция меритократии основывается на справедливости, которая в свою очередь выводится из идей прогресса и экономической эффективности, которые, подобно принципу блага в утилитаристских теориях, ставятся во 
главу угла. Соответственно, на вершине общественной иерархии, в соответствии с господствующими ценностями, должны находится те, кто вносит наибольший вклад в общественную продуктивность, т. е. наиболее талантливые. Однако такое - просвещенческое в своей основе - понимание достоинства и заслуг создает серьезные морально-этические проблемы, поскольку, как полагает М. Янг, оказывается ценностно-ограниченным в своем восприятии справедливости. Классическая традиция политической и моральной философии (Платон, Конфуций) также формировала меритократический идеал (цари-философы у Платона, добродетельный муж у Конфуция), однако отличие этого идеала от современного заключалось в том, что здесь понятие достоинства тесно было связано с понятием индивидуальной добродетели, достижения нравственного совершенства. Современная же меритократия, как показывает Янг, основана на воспевании «голого разума» и «голой эффективности». К тому же «меритократическая справедливость» в ее современной версии является разрушительной для общественных ценностей, солидарности, ибо укоренена в индивидуалистической культуре современного западного общества. В то же время нельзя отождествлять меритократию с либерализмом, поскольку либерализм (даже в его наиболее конкурентной американской «версии») тесно связан с идеями демократии, тогда как меритократия по сути представляет собой автократическое правление, где возможности социальных низов влиять на решения правящего класса фактически сведены к нулю (там же). Определенной попыткой преодолеть моральные недостатки меритократии явилась концепция американского социолога Д. Белла (Белл, 2004), согласно которому возвышение некоторых в обществе должно сопровождаться общественными гарантиями некоторого минимума благ для всех. Как отмечает П. Л. Карабущенко, «таким образом, меритократическое общество Д. Белла соединяет равное уважение всех с более или менее высокой степенью отличия некоторых» (Карабущенко, 1999: 208).

Однако даже несмотря на эти поправки, внесенные в концепции Белла, концепция меритократии все равно остается достаточно уязвимой для критики с точки зрения справедливости. Прежде всего, речь идет о так называемых контингентных (или случайных) обстоятельствах, одним из которых выступает неравное распределение природных дарований. Как показывает в своей «Теории справедливости» Дж. Ролз, данное распределение вполне можно уподобить неравному (и тоже случайному) распределению позиций в сословном обществе. Выходом из этого положения, однако, является не социальная нивелировка в отношении распределяемых социальных позиций или ресурсов, но такое использование обществом природных дарований, которое служит наибольшей выгоде наименее преуспевших. Т. е., иными словами, в обществе возможно неравенство, в том числе и основанное на природных дарованиях, однако это неравенство должно служить тому, чтобы те, кто этих дарований лишен, не чувствовали себя в чем-то ущемленными. Как указывает Ролз, «принцип различия представляет, в сущности, соглашение считать распределение естественных талантов в некоторых отношениях общим достоянием и разделять большие социальные и экономические выгоды, став- 
шие возможными за счет взаимно дополняющих аспектов этого распределения. Те, которые одарены от природы, кем бы они ни были, могут пользоваться этим только на тех условиях, что улучшат ситуацию тех, кому не сопутствовала удача. <...> Два принципа представляют собой честный путь воспрепятствовать произволу фортуны, и хотя они несовершенны в других отношениях, мы уверены в том, что институты, удовлетворяющие этим принципам, справедливы» (Ролз, 1995: 98-99). Иными словами, Ролз предлагает каждому, вступающему в общественный договор, хотя бы мысленно разделить судьбу другого, и потому, как указано в другом месте (там же: 101), принципы справедливости воспроизводят в своем содержании давно забытый в демократической теории идеал братства. Кроме того, чрезвычайно важным оказывается то обстоятельство, что теория «справедливости как честности» ставит во главу угла чувство самоуважения индивида, в то время как меритократические концепции это чувство подрывают.

Существо же теории Ролза заключается в том, что он предлагает провести некий мысленный эксперимент - представить, что индивиды оказались за занавесом неведения - т. е. он лишены важнейшей информации о самих себе (не знают ни своего пола, возраста, происхождения, социального статуса и т. д.). В итоге, какая стратегия в отношении выбора первичных благ окажется наиболее приемлемой для таких людей? Как показывает Ролз, наиболее приемлемым вариантом действия в данной ситуации неведения стала бы стратегия «максимин», т. е. максимизация минимума для всех, поскольку каждый в этой ситуации легко может себе представить, что именно он оказался в нижайшей позиции. И соответственно, рациональным для него является максимизация благ в этой позиции. Более конкретно Ролз формулирует три принципа справедливости, к которым в итоге должны прийти рационально действующие индивиды. Таким образом, Ролз отказывается от чисто эгалитарного подхода к справедливости и полагает, что социальные неравенства также являются морально оправданными, если они служат благосостоянию всех, а в особенности, наименее обеспеченных. И все же Ролз несомненно остается мыслителем либеральной направленности, поскольку свобода для него, как и для Р. Нозика (а также Дж. Локка и И. Канта) есть главнейшее. Поэтому справедливость, охраняющая свободу, для Ролза есть «первая добродетель общественных институтов» (Ролз, 1995: 19).

Концепция Ролза рассматривается как своеобразный эталон многими мыслителями и социальными теоретиками, однако есть влиятельные направления в современной мысли, которые относятся к ней критически. Это прежде всего различные представители как этики блага, так и этики права - к первым относятся коммунитаристы, и представители так называемой функционалистской теории блага или либерального перфекционизма. Ко вторым - представители либертарианства как особого направления внутри современного либерализма. Надо сказать, что первыми теорию Ролза подвергли критике именно представители либертарианской мысли, восходящей прежде всего к Локку. Среди последних особенно выделяются такие фигуры как Ф. А. фон Хайек и Р. Нозик. 
Существо этой критики связано с тем, что либертарианство главной и бескомпромиссной социальной ценностью считает индивидуальную свободу. Свобода с этой точки зрения предстает как необходимое условие самореализации индивида, преследующего собственные цели. Это - негативная свобода, «свобода от» (прежде всего от государства). Такое понимание свободы не предполагает предоставления каких-либо социальных благ, она есть чистая возможность для каждого добиваться в жизни того, что индивид способен достичь благодаря своим талантам и личным усилиям. «Либеральное требование свободы, - пишет Ф. А. фон Хайек, излагая свое видение “истинного” либерализма, - обращено... на устранение всех искусственных препятствий индивидуальным усилиям, но не содержит претензий к государству или общине о предоставлении определенных благ» (Хайек, 2003: 148; см. также: Хайек, 2006; Хайек, 1999).

Негативное понимание свободы предопределяло специфическое отношение к такой социальной ценности, как равенство. М. Фридмен называет три концепции равенства, которые последовательно сменяли друг друга в западном политическом дискурсе: личное равенство или равенство перед Богом, равенство возможностей, представляющее, по сути, конкретизацию первого вида равенства, и наконец, равенство результатов, которое заняло главенствующее положение в последней трети ХХ столетия. Из этих трех видов равенства с идеалом свободы, по мнению Фридмена, совместимы только равенство перед Богом и равенство возможностей: «Равенство возможностей, как и личное равенство, не противоречит свободе: наоборот, оно представляет собой существенную составную часть свободы» (Фридмен, 2003: 79). Резко отрицательно в этом смысле оценивается новый вид равенства — равенство результатов, в соответствии с которым предоставления свободы недостаточно, свобода должна быть обеспечена набором необходимых для нормального развития индивида социальных благ. Справедливое распределение, с точки зрения либертарианства, представляет собой не результат целенаправленных правительственных акций, но является результатом действия спонтанных, неконтролируемых рыночных сил. По известному замечанию фон Хайека, «не может быть никакой дистрибутивной справедливости там, где никто не распределяет. Справедливость имеет смысл только как норма человеческого поведения» (Хайек, 1999: 92).

Весьма близкую этой позицию занимает и коллега Ролза по Гарвардскому университету и один из главных его критиков Р. Нозик (Нозик, 2008). В своей теории Нозик различает минимальное и ультраминимальное государство, возникающие в результате выхода индивидов из состояния естественной анархии. Ультраминимальное государство - то, которое предоставляет защиту только тем, кто платит ему (является его клиентом). Минимальное же государство - то, которое равно обеспечивает защиту всем, находящимся на его территории. С точки зрения Нозика, именно минимальное государство является подлинно справедливым. С другой стороны, оно же является и в наибольшей мере морально оправданным, поскольку расширение функций государства за пределы защиты естественных прав должно рас- 
сматриваться как несправедливость. Всякие дистрибуции в рамках минимального государства, по Нозику, исключены. Таким образом, социальная справедливость - это не перераспределение, но совокупность правил, организующих пространство свободного обмена между людьми.

Такая позиция обоснованно критикуется за ее консерватизм. По мнению некоторых исследователей, она не затрагивает глубинных оснований экономической деятельности и регулирует лишь то, что лежит на поверхности социальной жизни (формальная справедливость) (Шамилева, 2005: 277; см. также: Шамилева, 2004). Согласно другим, данная позиция не может считаться подлинно моральной, поскольку по существу отражает ситуацию эгоизма собственников (Прокофьев, б/д: Электронный ресурс).

В то же время есть и немало общего, что связывает Ролза как левого либерала и представителей либертарианства. Прежде всего, это связь справедливости с моральной идеей честности. Справедливость это прежде всего способ обхождения с людьми как с равными, т. е. честно, без какой-либо дискриминации и нарушения прав. И леволиберальные, и либертарианские теории настаивают именно на таком отношении. Однако само понимание честности или равного обращения понимается в этих двух направлениях мысли по-разному. Если для либертарианцев честность - это, прежде всего, наличие честных процедурных условий, к каким бы результатам в итоге они не приводили (это может быть высокая степень социального неравенства), то для левых либералов действие принципа честности распространяется дальше только процедур - и распространяется на сами результаты социальноэкономической деятельности. Таким образом, для левых либералов принципиально важным оказывается не только традиционное либеральное равенство возможностей, но и равенство результатов.

Концепция Ролза подверглась (особенно в 1980-е гг.) активной критике со стороны различных представителей этики блага - коммунитаристов, так и представителей так называемой функционалистской теории блага или либерального перфекционизма. С точки зрения коммунитаристов, теория Ролза (как и теория Нозика) является индивидуалистической, а значит, искажает само понимание человеческого блага и справедливости, которые для коммунитаристов неразрывно связаны с сообществом. Представители же либерального перфекционизма критикуют теорию Ролза на том основании, что в ней справедливость сводится в основном к обладанию некими внешними (первичными) благами, и речь не идет о развитии человеческих качеств и достижении полноты человеческого существования (в соответствии с традицией Аристотеля). В определенной мере и коммунитаризм и либеральный перфекционизм можно рассматривать как попытки создать значимую альтернативу либеральной теории справедливости, идущей от Локка и Канта.

Коммунитаризм - направление в современной англо-американской политической философии, возникшее в 1980-е гг. в ответ на распространение идей современного либерализма (Алексеева, 2000; Кашников, 2004; Дмитриев, 2009; Кимлика, 2010). В противоположность либералам коммунитаристы (среди которых такие видные философы, как А. Этциони, Ч. Тейлор, М. Сэн- 
дел, М. Уолцер, А. Макинтайр) отстаивают первичность не индивидуальной свободы и абстрактных прав, но определенным образом понимаемого сообщества (community). Более того, коммунитаризм как направление мысли далеко не ограничивается только академической средой - сегодня он представляет широкое общественное движение (прежде всего в США), направленное на возрождение традиционных ценностей американского образа жизни (Алексеева, 2000: 202).

Особенность коммунитаризма как идейного и политического течения в том, что он выступает как антииндивидуализм, как своего рода возвышенноидеалистическое мироощущение-мировоззрение, которое и становится источником социальной критики. Суть коммунитаристского взгляда на общество сводится к следующему: жизнь человека в обществе предполагает не только заботу об индивидуальных правах, но и в не меньшей степени - заботу о благе сообщества (общем благе). В основе этого представления особое, свойственное коммунитаристам, чувство принадлежности к сообществу. Если для либералов индивид - это скорее «изолированный атом», лишь волей случая оказавшийся в данных социальных обстоятельствах (а потому имеющий лишь договорные, «сдельные», отношения с этой общностью, которые возможно в любой момент пересмотреть), то для коммунитаристов человек - всегда носитель определенной социальной идентичности («самотождественности»). Эта идентичность (конкретное представление о том, кто я есть, какова моя социальная роль, мои унаследованные социальные обязательства и т. д.) и определяет, согласно коммунитаристам, меня как меня, т. е. как представителя определенной общности (семьи, дома, города, нации и т. д.).

Из этого чувства, понимания человека как члена коммуны, связанного с ней нерасторжимыми моральными узами, вытекает и обязанность по поддержанию блага этой коммуны, от которого, с данной точки зрения, неотделимо благо отдельного индивида (Макинтайр, 2000: 297-298).

Еще один важный момент, характеризующий позицию коммунитаризма и одновременно составляющий ключевой пункт современных политических дискуссий (Кимлика, 2010: 275-287) - это моральный перфекционизм. Коммунитаристы считают, что для того, чтобы благо сообщества эффективно поддерживалось, необходимо воспитывать в гражданах определенные моральные качества - добродетели. Эти добродетели есть то, что позволит индивиду правильно ориентироваться в окружающей действительности и прежде всего совершать правильные (т. е. нужные сообществу, ценные с его точки зрения) поступки. В свою очередь, это требует ранжирования (т. е. концептуального упорядочивания) различных образов жизни в зависимости от того, насколько каждый из них способствует достижению общего блага.

Глубокую критику моральных оснований современного либерализма осуществил в своей концепции американский философ-коммунитарист М. Сэндел. Так, в своей книге «Справедливость» (Сэндел, 2013) философ рассматривает вполне практический вопрос о том, нужно ли народам и их отдельным представителям (прежде всего политикам) приносить извинения и 
осуществлять репарации в отношении других народов, когда-то пострадавшим от несправедливых (и даже преступных) действий первых. В этом отношении Сэндел обнаруживает две противоположные позиции: так, с точки зрения первой, такие извинения и репарации необходимы, поскольку люди, как часть определенного национального сообщества, несут ответственность за деяния своих предшественников. С точки зрения же второй позиции нет, такие действия люди не обязаны совершать, поскольку то, что было совершено когда-то, не имеет отношения к нашему моральному опыту. В основе этих двух точек зрения, как показывает Сэндел, лежат две совершенно разных моральных онтологии - в основе первой лежит концепция личности, которая на глубинном уровне связывает себя со своим сообществом (нарративная концепция личности, по А. Макинтайру), в основе другой - современная либеральная концепция, восходящая к Локку и Канту. В соответствии с этой, второй, концепцией, индивид ответственен лишь за то, что явилось предметом его собственного выбора как автономной личности. Эта концепция предписывает лишь уважать положения всеобщего закона и соблюдать заключенные (с другими людьми) соглашения. Как пытается доказать Сэндел на множестве примеров из реальной жизни, такая концепция личности является дефектной, поскольку она не учитывает третьего типа обязательств конкретных обязательств перед своим сообществом или группой, которые несет каждый человек и которые не проистекают из его индивидуального выбора. Таким образом, как показывает Сэндел, не меньшую роль, чем обязательства справедливости в духе Канта и Ролза, имеют обязательства, связанные с человеческой солидарностью, - более того, эти моральные обязанности могут входить в конфликт с требованиями абстрактной справедливости. Еще один важный момент, на котором настаивает Сэндел, - это необходимость преодоления моральной нейтральности в политике. Несомненно, существует определенная опасность навязывания представлений о хорошей жизни в рамках перфекционистского сообщества, однако попытка полного устранения концепций блага из политической (публичной) сферы ведет к оскудению и деградации политики. Поэтому политическая жизнь с ее обсуждениями самых злободневных вопросов (таких как аборты, опыты на стволовых клетках, отношение к гомосексуальным бракам и др.) - как пытается показать Сэндел - с неизбежностью требует вовлечения оценочных суждений, проистекающих из различных представлений о благой жизни.

Влиятельную позицию в рамках современного коммунитарного дискурса справедливости занимает концепция философа-аристотелианца А. Макинтайра. Согласно Макинтайру, общая моральная ситуация современных обществ представляет собой ситуацию глубокого морального упадка (Макинтайр, 2000). Это связано с тем, что в современном секуляризированом мире фактически оказались разрушенными различные моральнополитические традиции, которые были характерны для досовременных обществ, следовательно, мораль в современных обществах перестали представлять собой нечто целостное, превратившись в набор разнородных, бессвязных этических максим. Эту противоречивость современного морального 
дискурса Макинтайр демонстрирует на примере сопоставления концепций справедливости Ролза и Нозика. Он показывает, что если основанием справедливости для Нозика являются права, то аналогичным основанием для Ролза выступают потребности, и соответственно, моральный спор между двумя конкурирующими концепциями становится в принципе неразрешимым (поскольку они исходят из принципиально различных оснований) (там же: 336337). Способом же преодоления такого положения, по Макинтайру, могло бы стать обращение к понятию заслуг, что однако приемлемо только в рамках сообщества, где все разделяют одинаковые ценности. Либеральное же общество - это не сообщество, а собрание чужаков, где обращение к понятию заслуг в принципе проблематично. Для того, чтобы продемонстрировать значение этого морального критерия и его влияние на разрешение моральнополитических коллизий, Макинтайр обращается к этико-политической концепции Аристотеля (MacIntyre, 1988). Аристотелевский полис в описании Макинтайра представляет собой иерархически организованное сообщество, где все социальные практики находятся в четко упорядоченном положении относительно друг друга, а значимость заслуг определяется в зависимости от того, в рамках какой практики они достигаются. Наиболее ценными видами практик считаются политика и законодательство. В целом такая жесткая иерархическая организация социального и политического пространства, по Макинтайру, должна продемонстрировать подлинно непротиворечивую работу практической рациональности. Однако теория Аристотеля-Макинтайра являет собой образец современной утопии, поскольку воплотить данные принципы в жизнь является возможным лишь в замкнутых локальных сообществах (Макинтайр, 2000: 341).

Надо сказать, что коммунитаристская критика в значительной мере была усвоена Ролзом в его более поздних работах — во всяком случае, он отказался от своего первоначального понимания справедливости как результата некой абстрактной (универсальной) процедуры: так, в книге «Политический либерализм» (Rawls, 2005) американский философ рассматривает три принципа справедливости уже как «произведение» особого типа политической культуры - либерально-демократической, присущей прежде всего западному обществу. Кроме того, философ выдвигает целый ряд новых идей (идеи «перекрещивающегося консенсуса» и др.) для того, чтобы сформулировать теорию, адекватную современным вызовам мультикультурализма. В целом, можно сказать, что в работах позднего Ролза теория «справедливости как честности» претерпела существенные метаморфозы (став значительно ближе к коммунитаризму), сохранив однако свое нормативное и ценностное содержание.

Наряду с коммунитаризмом влиятельную альтернативу ролзианскому пониманию справедливости представляют т. н. функционалистские теории человеческого блага, представленные прежде всего в работах двух известных современных философов - А. Сена и М. Нуссбаум (Сен, 2004; Сен, 2016; Nussbaum, 2000). В отличие от коммунитаризма, данные теории являются индивидуалистическими и по сути либеральными, однако то, что их отличает 
от ролзианского (деонтологического) либерализма, - наличие качественной концепции человеческого блага, которая должна быть положена в основу концепции справедливости. Иначе эти концепции (прежде всего, концепцию Нуссбаум) относят к одному из вариантов современного этического аристотелианства (наряду с концепцией Макинтайра) (Прокофьев, 2001).

В своей книге 2009 года «Идея справедливости» (Сен, 2016) индийский экономист и философ, лауреат Нобелевской премии по экономике 1998 года А. Сен развивает подход, который он называет сравнительным подходом, или подходом, основанным на оценке возможностей. Он, как показывает Сен, генетически связан с идеями ряда мыслителей эпохи Просвещения, однако противостоит подходу, называемому философом «трансцендентальным институционализмом», который составляет магистральную линию классических и современных размышлений о справедливости. В частности, в духе трансцендентального институционализма сформулированы все договорные концепции справедливости, начиная с эпохи раннего Нового времени (Т. Гоббс, Дж. Локк, И. Кант, сегодня - Дж. Ролз, Р. Дворкин и др.). Сутью подхода Сена, отличающего его от трансцендентального институционализма, является то, что акцент делается на том, как справедливость реализуется в реальной жизни, какова степень реализации справедливости в том или ином конкретном обществе, а не просто на воплощении той или иной справедливой институциональной структуры. Иными словами, если трансцендентальный институционализм фиксируется на неких параметрах идеального справедливого общества (при этом сами идеалы у разных философов могут существенно отличаться), то сравнительный подход основывается на анализе конкретных, сейчас существующих несправедливостей и необходимости их устранения. Более конкретно данный подход описывается у Сена через понятие функциональных возможностей. Возможности, как показывает Сен это конкретные шансы для данного человека быть успешным. При этом, существует серьезное отличие данного подхода от т. н. ресорсистских теорий справедливости (Дж. Ролз, Р. Дворкин). В ресорсистских теориях утверждается, что справедливость будет достигнута, если человеку будет обеспеченно получение какого-то количества необходимых ресурсов или первичных благ (при этом теоретики данного направления, такие, например, как Р. Дворкин, учитывают возможность того, что человек может подвергнуться каким-то несчастливым случайностям фортуны - например, обладать ограниченными возможностями, - для чего предусмотрены дополнительные процедуры обеспечения ресурсами). С точки зрения же подхода, основанного на возможностях, справедливого распределения благ может оказаться совершенно недостаточно, поскольку, например, человек с ограниченными возможностями, во-первых, имеет меньше возможностей для зарабатывания средств, а вовторых, его потребность в дополнительных средствах выше, чем у обычного человека. Поэтому получается, что одна и та же степень наделения ресурсами может означать неравные возможности для разных категорий граждан. Вследствие этого подход Сена фиксируется на том, как и какими средствами возможно обеспечить людям реальные шансы добиваться того, что человек 
считает для себя ценным (и это предполагает анализ не только ресурсов, но и всего многообразия реальных жизненных обстоятельств).

Более детальную разработку подход, основанный на оценке возможностей, получил у коллеги и ученицы Сена американского философа М. Нуссбаум. В своей концепции она выделяет десять основных функциональных возможностей человека:

1) способность прожить нормальную жизнь;

2) телесное здоровье;

3) телесная целостность;

4) чувства, воображение и мышление;

5) эмоции;

6) практический разум;

7) связь с другими людьми;

8) отношения с иными живыми существами;

9) способность к игре;

10) контроль над собственной экономической и политической средой.

Общественная справедливость при этом трактуется как воплощение в данном конкретном обществе шансов развивать потенциальные возможности человека (human capabilities). То общество, где созданы условия для такого развития, будет обществом справедливым, напротив, общество, где такие условия не создаются, является несправедливым (Nussbaum, 1992: 229). Таким образом, черпая вдохновение в некоторых положениях теории Аристотеля, а также у раннего К. Маркса, функционалистская концепция оказывается весьма близкой социал-демократическому пониманию справедливости, получившему воплощение, в частности, в политике скандинавских государств. Развернутое описание справедливой политии М. Нуссбаум дает в своей известной статье «Аристотелианская социал-демократия» (Nussbaum, 1990).

Надо сказать, что данная теория является перфекционистской (хотя и эгалитарной), поскольку реализация справедливости предполагает осуществление постоянных сравнений жизненных векторов разных людей, или, что то же самое, сравнительную оценку их качества жизни (Подузов, 2008). В то же время это именно либеральный перфекционизм, поскольку развивать или не развивать те или иные функции (например, получать или не получать качественное образование) - дело выбора конкретного индивида. Государство должно лишь предоставить соответствующие условия для саморазвития. Важно отметить, что основные положения данного подхода получили широкое признание в мире и стали основой докладов о развитии человеческого потенциала.

Анализируя современные подходы к осмыслению справедливости, нельзя обойти вниманием концепцию французских авторов Люка Болтански и Лорана Тевено, изложенную ими в книге «Критика и обоснование справедливости» (Болтански, Тевено, 2013). Эта концепция отличается значительной оригинальностью, и одна из ее особенностей в том, что она фактически никак не соотносится с теми морально-политическими дебатами, которые характе- 
ризовали западный дискурс справедливости с начала 1970-х гг. В определенной мере ее можно соотнести с проанализированной выше концепцией А. Сена, поскольку подход к справедливости, реализуемый указанными авторами, также носит прагматический характер. Как пишут Болтански и Тевено, «особенность нашего подхода в том, что, в отличие от традиционных исследований справедливости, в фокусе внимания оказываются не трансцендентные законы, а требования прагматического характера, определяющие релевантность (pertinence) того или иного «диспозитива» (dispositif), то есть набора используемых в качестве доказательств фактов и предметов, или, если хотите, его правильность и адекватность ситуации (justesse)» (там же: 29; курсив источника. - $Г$. К.). Авторы подчеркивают, что они придерживаются расширительного понимания справедливости: справедливость это не просто нахождение правильно пропорциональности в отношениях между людьми, но также и всякая другая (в том числе, техническая) упорядоченность. Согласно Болтански и Тевено, основной предмет их исследования - ситуации согласия и разногласия в отношениях между людьми. Человеческие существа обладают естественной способностью к сближению друг с другом, однако проблема заключается в том, как, каким образом, в соответствии с какими принципами будет происходить это сближение. Суть концепции французских ученых заключается как раз в том, чтобы выявить наиболее общие принципы такого сближения и исследовать различного рода взаимоотношения между этими принципами, возникающими в реальных жизненных ситуациях. Таким образом, ключевым понятием концепции Болтански и Тевено становится понятие града, или, иными словами, некоторого определенного порядка справедливости, который управляется собственным «принципом величия» (личная преданность, богатство, оценка окружающих, полезность, вдохновение, служение общим интересам). В соответствии с этим принципом (принципами) происходит естественное ранжирование людей в различных порядках справедливости - патриархальном, рыночном, гражданском, мире репутации, мире вдохновения, научно-техническом мире. Каждый из этих миров обладает собственными, только ему присущими характеристиками, которые в «чистом» виде можно обнаружить в произведениях политической философии. Ключевая особенность данной концепции в том, что она является динамической, и рассматривает прежде всего, различные ситуации оспаривания, в которых сомнению подвергается наличное положение дел (например, порядок распределения внутри одного града, или же происходит конкуренция между различными принципами справедливости, относящимися к разным мирам).

\section{ЗАКЛЮЧЕНИЕ.}

\section{СПРАВЕДЛИВОСТЬ: КАК ЕЕ ПОНИМАТЬ СЕГОДНЯ?}

Таким образом, можно констатировать, что за многовековую историю социальной и политической мысли категория справедливости подверглась значительным трансформациям. Античное понимание связывает ее с понятием блага, тогда как новоевропейское - с понятием права. Существенные 
различия в понимании справедливости обозначились также в эпоху «великих идеологий» (XIX в.), и были связаны с формированием либеральной, консервативной и левой (марксистской) мысли. Современные дискуссии о справедливости связаны с концепцией Дж. Ролза «справедливости как честности», которая, в свою очередь, стала реакцией на два влиятельных направления в политической мысли - утилитаризм и теорию меритократии. В свою очередь, теория Ролза подверглась критике как слева, так и справа - со стороны представителей этики блага (прежде всего, коммунитаристов), так и этики права (либертарианцев). Особенно напряженными, но и теоретически плодотворными стали дискуссии Ролза и его последователей с представителями коммунитаристской мысли. Однако несмотря на общую популярность теории Ролза в академической среде, сохраняющуюся до сих пор, как и наличие влиятельных теоретических альтернатив, думается, что подходы, опирающиеся на более реалистическое осмысление справедливости, являются и более плодотворными. Например, подход, основный на анализе человеческих возможностей. Его преимущества видятся прежде всего в том, что оставаясь либеральным и индивидуалистическим по существу (что соответствует тенденциям развития современных обществ), он в то же время опирается на сильную концепцию человеческого блага. И, таким образом, позволяет избежать тех недостатков, которые традиционно присущи либеральным теориям. Следовательно, справедливость в ее современном понимании можно определить как нормативное требование развития важнейших человеческих возможностей, которые определяют полноценное функционирование каждого человеческого существа. А обязанность государства в этом контексте заключается в предоставлении возможностей для такого развития (и саморазвития) индивида. Отметим, что эта концепция представляет интерес не только на уровне отдельных стран, но и для решения проблемы глобальной справедливости, которая вышла сегодня на первый план в мировых дискуссиях (Апресян, Гусейнов, Прокофьев, 2005; Аитова, 2011; Прокофьев, 2013). Эскиз концепции справедливости, основанной на понятии функциональных возможностей человека, представлен М. Нуссбаум в одной из ее работ и является значимой альтернативой, в частности, подходу к глобальной справедливости Дж. Ролза (Nussbaum, 2005). Думается также, что весьма плодотворным является и подход, предложенный французскими авторами Л. Болтански и Л. Тевено рассмотрение справедливости через понятие градов, особых нормативных порядков, в рамках которых происходит справедливое упорядочение совместной жизни людей в обществе. Ценность данной концепции видится прежде всего в том, что она позволяет анализировать общество как сложный динамичный процесс, в котором происходит постоянный пересмотр сложившегося положения вещей, что свойственно подлинно демократической политике. Появляются также значимые исследования, связывающие идею справедливости с конкретными социальными контекстами, например, с городским пространством (Харви, 2018). В целом можно зафиксировать тенденцию, в соответствии с которой осмысление справедливости в современном мире становится все менее метафизическим и все более приближенным к ре- 
альности, что позволяет лучше решать проблемы, возникающие в современном социуме.

\section{СПИСОК ЛИТЕРАТУРЫ}

Аитова, Г. Ш. (2011) Новое в понимании справедливости в эпоху глобализации: социально-философский анализ : автореф. дис. ... канд. филос. наук / ИФ РАН. М. 34 с.

Алексеева, Т. А. (2000) Современные политические теории. Опыт Запада. М. : Российская политическая энциклопедия (РОССПЭН). 479 с.

Апресян, Р. Г., Гусейнов, А. А., Прокофьев, А. В. (2005) Проблема справедливости в глобальной перспективе // Диалог культур в глобализирующемся мире: мировоззренческие основания и ценностные приоритеты / отв. ред. В. С. Степин, А. А. Гусейнов. М. : Наука. 427 с. С. 122-150.

Белл, Д. (2004) Грядущее постиндустриальное общество. Опыт социального прогнозирования / пер. с англ. Изд. 2-е, испр. и доп. М. : Academia. CLXX, $788 \mathrm{c}$.

Бентам, И. (1998) Введение в основания нравственности и законодательства / пер. с англ. Б. Г. Капустина. М. : Российская политическая энциклопедия (РОССПЭН). 416 с.

Берк, Э. (1993) Размышления о революции во Франции и заседаниях некоторых обществ в Лондоне, относящихся к этому событию / сокр. пер. с англ. Е. И. Гельфанд ; предисл. К. К. О’Брайена. М. : Рудомино. 143, [1] с.

Болтански, Л., Тевено, Л. (2013) Критика и обоснование справедливости: Очерки социологии градов / пер. с фр. О. В. Ковеневой под науч. ред. Н. Е. Копосова. М. : Новое литературное обозрение. 576 с.

Дмитриев, Т. А. (2009) Коммунитаризм // Современная западная философия. Энциклопедический словарь / под ред. О. Хеффе, В. С. Малахова, В. П. Филатова при участии Т. А. Дмитриева ; Ин-т философии. М. : Культурная революция. 392 с. С. 17-20.

Канарш, Г. Ю. (2018) Справедливость // Философская антропология. T. 4. № 1. C. 244-262. DOI: 10.21146/2414-3715-2018-4-1-244-262

Канарш, Г. Ю. (2011) Социальная справедливость: философские концепции и российская ситуация. М. : Изд-во Моск. гуманит. ун-та. 236 с.

Карабущенко, П. Л. (1999) Антропологическая элитология. М. ; Астрахань : Изд-во Астраханского филиала МОСУ. 231 с.

Кашников, Б. Н. (2004) Либеральная теория справедливости и политическая практика России. Великий Новгород : НовГУ им. Ярослава Мудрого. $260 \mathrm{c}$.

Кимлика, У. (2010) Современная политическая философия: введение / пер. с англ. С. Моисеева. М. : Изд. дом Гос. ун-та - Высшей школы экономики. 592 с.

Кроль, М. (б/д) Меритократия как царство разума [Электронный ресурс] // Лаборатория социальных инноваций Cloudwatcher. URL: http://cw.ru/ 
analytics/3/view/35/ [архивировано в WaybackMachine] (дата обращения: 08. 01.2019).

Макинтайр, А. (2000) После добродетели: Исследования теории морали / пер. с англ. В. В. Целищева. М. : Академический Проект ; Екатеринбург : Деловая книга. 384 с.

Манхейм, К. (1994) Консервативная мысль // Манхейм К. Диагноз нашего времени / пер. с нем. и англ. М. : Юристъ. 700 с. С. 572-668.

Местр, Ж. де. (1997) Рассуждения о Франции / пер. с фр. Г. А. Абрамова, Т. В. Шмачкова. М. : Российская политическая энциклопедия (РОССПЭН). 216 c.

Милль, Д. С. (2013) Утилитаризм / пер. с англ. ; предисл. А. С. Земерова. Ростов-на-Дону : Донской издательский дом. 240 с.

Нозик, Р. (2008) Анархия, государство и утопия / пер. с англ. Б. Пинскера под ред. Ю. Кузнецова и А. Куряева. М. : ИРИСЭН. 424 с.

Подузов, А. А. (2008) Философия уровня жизни. Очерк современных представлений // Научные труды: Институт народнохозяйственного прогнозирования РАН. Т. 6. С. 72-95.

Прокофьев, А. В. (2001) Человеческая природа и социальная справедливость в современном этическом аристотелианстве // Этическая мысль : ежегодник. Вып. 2. М. : ИФ РАН. 231 с. С. 41-64.

Прокофьев, А. В. (2010) Понятие «социальная справедливость» в трудах Дж. С. Милля // Историко-философский ежегодник. № 2009. С. 135-155.

Прокофьев, А. В. (2013) Воздавать каждому должное... Введение в теорию справедливости. М. : Альфа-М. 512 с.

Прокофьев, А. В. (б/д) Социальная справедливость: нормативное содержание и история становления понятия [Электронный ресурс] // Институт философии PAH. URL: https://iphras.ru/page30194324.htm [архивировано в WaybackMachine] (дата обращения: 08.01.2019).

Ролз, Дж. (1995) Теория справедливости / пер. В.В.Целищева при участии В. Н. Карповича и А. А. Шевченко ; науч. ред. В. В. Целищев. Новосибирск : Изд-во Новосиб. ун-та. 534, [1] с.

Ролз, Дж. (2010) Теория справедливости / пер. с англ. В. Карпович, А. Шевченко ; науч. ред. и предисл. В. В. Целищева. Изд. 2-е. М. : Изд-во ЛКИ. $536 \mathrm{c}$.

Сен, А. (2004) Развитие как свобода / пер. с англ. ; под ред. и с послесл. Р. М. Нуреева. М. : Новое издательство. 425 с.

Сен, А. (2016) Идея справедливости / пер. с англ. Д. Кралечкина ; науч. ред. перевода В. Софронов, А. Смирнов. М. : Изд-во Института Гайдара ; Фонд «Либеральная миссия». 517, [1] с.

Сэндел, М. (2013) Справедливость. Как поступать правильно? / пер. с англ. А. Калинина. М. : Манн, Иванов и Фербер. 352 с.

Фридмен, М. (2003) Свобода, равенство и эгалитаризм // Фридмен М., Хайек Ф. О свободе. Челябинск : Социум ; М. : Три квадрата. 182 с. С. $73-$ 106. (Серия «Философия свободы», вып. II). 
Хайек, Ф. (1999) Познание, конкуренция и свобода / пер., сост. и предисл. С. Мальцевой. СПб. : Пневма. 287 с.

Хайек, Ф. (2003) Либерализм // Фридмен М., Хайек Ф. О свободе. Челябинск : Социум ; М. : Три квадрата. 182 с. С. 129-168. (Серия «Философия свободы», вып. ІІ).

Хайек, Ф. (2006) Право, законодательство и свобода: современное понимание либеральных принципов справедливости и политики / пер. с англ. Б. Пинскера и А. Кустарева под ред. А. Куряева. М. : ИРИСЭН. 644 с.

Харви, Д. (2018) Социальная справедливость и город / пер. с англ. Е. Ю. Герасимовой. М. : Новое литературное обозрение. 440 с.

Шамилева, Р. К. (2004) Модели справедливости в современной либеральной теории Запада. М. : Макс Пресс. 260 с.

Шамилева, Р. К. (2005) Либеральная концепция справедливости: миф или реальность? // Социально-гуманитарные знания. № 6. С. 269-279.

Штраус, Л. (2000) Прогресс или возврат? Современный кризис западной цивилизации // Штраус Л. Введение в политическую философию / пер. с англ. М. Фетисова. М. : Логос ; Праксис. 364 с. С. 264-293.

MacIntyre, A. (1988) Whose justice? Which rationality? L. : Duckworth. xi, $410 \mathrm{p}$.

Nussbaum, M. (1990) Aristotelian social democracy // Liberalism and the good / ed. by R. B. Douglass, G. M. Mara, H. S. Richardson. N. Y. : Routledge. viii, 289 p. P. 203-252.

Nussbaum, M. C. (1992) Human functioning and social justice: In defense of Aristotelian essentialism // Political Theory. Vol. 20. No. 2. P. 202-246.

Nussbaum, M. C. (2000) Women and human development: The capabilities approach. Cambridge ; N. Y. : Cambridge University Press. xxi, 312 p. (John Robert Seeley lectures).

Nussbaum, M. C. (2005) Beyond the social contract: Capabilities and global justice // The political philosophy of cosmopolitanism / ed. by G. Brock, H. Brighouse. Cambridge : Cambridge University Press. x, 262 p. P. 196-218.

Rawls, J. (1971) A theory of justice. Cambridge, MA : Belknap Press of Harvard University Press. xv, 607 p.

Rawls, J. (2005) Political liberalism. Expanded edn. N. Y. : Columbia University Press. lx, 525 p.

Young, M. (1961) The rise of the meritocracy. 1870-2033 : An essay on education and equality. Harmondsworth : Penguin Books. 189 p.

Дата поступления: 10.01.2019 г.

\section{REFERENCES}

Aitova, G. Sh. (2011) Novoe v ponimanii spravedlivosti $v$ epokhu globalizatsii: sotsial'no-filosofskii analiz [New understandings of justice in the age of globalization: A social and philosophical analysis] : Abstract of the diss. ... Can- 
didate of Philosophy / Institute of Philosophy, Russian Academy of Sciences. Moscow. 34 p. (In Russ.).

Alekseeva, T. A. (2000) Sovremennye politicheskie teorii. Opyt Zapada [Contemporary political theories. Western experience]. Moscow : Rossiiskaia politicheskaia entsiklopediia Publ. (ROSSPEN) [Russian Political Encyclopedia]. 479 p. (In Russ.).

Apresian, R. G., Guseinov, A. A. and Prokofiev, A. V. (2005) Problema spravedlivosti $\mathrm{v}$ global'noi perspektive [The issue of justice in global perspective]. In: Dialog kul'tur v globaliziruiushchemsia mire: mirovozzrencheskie osnovaniia i tsennostnye prioritety [The dialogue of cultures in globalizing world: Worldview foundations and axiological priorities] / ed. by V. S. Stepin and A. A. Guseinov. Moscow : Nauka Publ. 427 p. Pp. 122-150. (In Russ.).

Bell, D. (2004) Griadushchee postindustrial'noe obshchestvo. Opyt sotsial'nogo prognozirovaniia [The coming of post-industrial society: A venture in social forecasting] / transl. from English. 2nd edn., revised and enlarged. Moscow : Academia Publ. CLXX, 788 p. (In Russ.).

Bentham, J. (1998) Vvedenie v osnovaniia nravstvennosti i zakonodatel'stva [An introduction to the principles of morals and legislation] / transl. from English by B. G. Kapustin. Moscow : Rossiiskaia politicheskaia entsiklopediia Publ. (ROSSPEN) [Russian Political Encyclopedia]. 416 p. (In Russ.).

Burke, E. (1993) Razmyshleniia o revoliutsii vo Frantsii $i$ zasedaniiakh nekotorykh obshchestv $v$ Londone, otnosiashchikhsia $k$ etomu sobytiiu [Reflections on the revolution in France, and on the proceedings in certain societies in London relative to that event] / abridged transl. from English by E. I. Gelfand ; foreword by C. C. O’Brien. Moscow : Rudomino Publ. 143, [1] p. (In Russ.).

Boltanski, L. and Thévenot, L. (2013) Kritika i obosnovanie spravedlivosti: Ocherki sotsiologii gradov [On justification: The economies of worth] / transl. from French by O. V. Koveneva ed. by N. E. Koposov. Moscow : Novoe literaturnoe obozrenie Publ. 576 p. (In Russ.).

Dmitriev, T. A. (2009) Kommunitarizm [Communitarianism]. In: Sovremennaia zapadnaia filosofiia. Entsiklopedicheskii slovar' [Contemporary Western philosophy. Encyclopedic dictionary] / ed. by O. Kheffe, V. S. Malakhov and V. P. Filatov in consultation with T. A. Dmitriev ; Institute of Philosophy. Moscow : Kul'turnaia revoliutsiia Publ. 392 p. Pp. 17-20. (In Russ.).

Kanarsh, G. Yu. (2018) Spravedlivost' [Justice]. Filosofskaia antropologiia, vol. 4, no. 1, pp. 244-262. DOI: 10.21146/2414-3715-2018-4-1-244-262

Kanarsh, G. Yu. (2011) Sotsial'naia spravedlivost': filosofskie kontseptsii i rossiiskaia situatsiia [Social justice: Philosophical conceptions and Russian situation]. Moscow : Moscow University for the Humanities Publ. 236 p. (In Russ.).

Karabushchenko, P. L. (1999) Antropologicheskaia elitologiia [Anthropological elitology]. Moscow ; Astrakhan : Publ. of Astrakhan Branch of Moscow Open Social University. 231 p. (In Russ.). 
Kashnikov, B. N. (2004) Liberal'naia teoriia spravedlivosti i politicheskaia praktika Rossii [Liberal theory of justice and political practice in Russia]. Veliky Novgorod : Yaroslav-the-Wise Novgorod State University Publ. 260 p. (In Russ.).

Kymlicka, W. (2010) Sovremennaia politicheskaia filosofiia: vvedenie [Contemporary political philosophy: An introduction] / transl. from English by S. Moiseev. Moscow : Higher School of Economics Publishing House. 592 p. (In Russ.).

Krol, M. (s/d) Meritokratiia kak tsarstvo razuma [Meritocracy as a realm of reason]. Laboratoriia sotsial'nykh innovatsii Cloudwatcher [online] Available at: http://cw.ru/analytics/3/view/35/ [archived in WaybackMachine] (accessed 08.01. 2019).

MacIntyre, A. (2000) Posle dobrodeteli: Issledovaniia teorii morali [After virtue: A study in moral theory] / transl. from English by V. V. Tselishchev. Moscow : Akademicheskii Proekt Publ. ; Ekaterinburg : Delovaia kniga Publ. 384 p. (In Russ.).

Mannheim, K. (1994) Konservativnaia mysl' [Conservative thought]. In: Mannheim, K. Diagnoz nashego vremeni [Diagnosis of our time] / transl. from German and English. Moscow : Iurist" Publ. 700 p. Pp. 572-668. (In Russ.).

Maistre, J. de. (1997) Rassuzhdeniia o Frantsii [Considerations on France] / transl. from French by G. A. Abramov and T. V. Shmachkov. Moscow : Rossiiskaia politicheskaia entsiklopediia Publ. (ROSSPEN) [Russian Political Encyclopedia]. 216 p. (In Russ.).

Mill, D. S. (2013) Utilitarizm [Utilitarianism] / transl. from English ; foreword by A. C. Zemerov. Rostov-on-Don : Donskoi izdatel'skii dom [Don Publishing House]. 240 p. (In Russ.).

Nozick, R. (2008) Anarkhiia, gosudarstvo i utopiia [Anarchy, state, and utopia] / transl. from English by B. Pinsker ed. by Yu. Kuznetsov and A. Kuriaev. Moscow : IRISEN Publ. 424 p. (In Russ.).

Poduzov, A. A. (2008) Filosofiia urovnia zhizni. Ocherk sovremennykh predstavlenii [The philosophy of the standard of living. An essay on current ideas]. Nauchnye trudy: Institut narodnokhoziaistvennogo prognozirovaniia RAN, vol. 6 . pp. 72-95. (In Russ.).

Prokofiev, A. V. (2001) Chelovecheskaia priroda i sotsial'naia spravedlivost' $\mathrm{v}$ sovremennom eticheskom aristotelianstve [Human nature and social justice in contemporary ethical Aristotelianism]. In : Eticheskaia mysl' [Ethical thought] : A yearbook. Issue 2. Moscow : Institute of Philosophy Publ. 231 p. Pp. 41-64. p. (In Russ.).

Prokofiev, A. V. (2010) Poniatie «sotsial'naia spravedlivost'» v trudakh Dzh. S. Millia [Concept of “social justice” in J. S. Mill’s works]. Istoriko-filosofskii ezhegodnik, no. 2009, pp. 135-155. (In Russ.).

Prokofiev, A. V. (2013) Vozdavat' kazhdomu dolzhnoe... Vvedenie v teoriiu spravedlivosti [To mete out justice for everyone... An introduction to the theory of justice]. Moscow : Al'fa-M Publ. 512 p. (In Russ.). 
Prokofiev, A. V. (s/d) Sotsial'naia spravedlivost': normativnoe soderzhanie i istoriia stanovleniia poniatiia [Social justice: Normative content and the history of concept's development]. Institut filosofii RAN [Institute of Philosophy]. [online] Available at: https://iphras.ru/page30194324.htm [archived in WaybackMachine] (accessed 08.01.2019).

Rawls, J. (1995) Teoriia spravedlivosti [A theory of justice] / transl. by V. V. Tselishchev in consultation with V. N. Karpovich and A. A. Shevchenko ; ed. by V. V. Tselishchev. Novosibirsk : Novosibirsk University Publ. 534, [1] p. (In Russ.).

Rawls, J. (2010) Teoriia spravedlivosti [A theory of justice] / transl. from English by V. Karpovich and A. Shevchenko ; ed. and foreword by V. V. Tselishchev. 2nd edn. Moscow : LKI Publ. 536 p. (In Russ.).

Sen, A. (2004) Razvitie kak svoboda [Development as freedom] / transl. from English ; ed. by and afterword by R. M. Nureev. Moscow : Novoe izdatel'stvo Publ. 425 p. (In Russ.).

Sen, A. (2016) Ideia spravedlivosti [The Idea of justice] / transl. from English by D. Kralechkin ; ed. by V. Sofronov and A. Smirnov. Moscow : Gaidar Institute Publ. ; Liberal'naia missiia Foundation. 517, [1] p. (In Russ.).

Sendel, M. (2013) Spravedlivost'. Kak postupat' pravil'no? [Justice. What's the right thing to do?] / transl. from English by A. Kalinin. Moscow : Mann, Ivanov i Ferber Publ. 352 p. (In Russ.).

Friedman, M. (2003) Svoboda, ravenstvo i egalitarizm [Freedom, equality and egalitarianism]. In: Friedman, M. and Hayek, F. O svobode [On freedom]. Chelyabinsk : Sotsium ; Moscow : Tri kvadrata Publ. 182 p. Pp. 73-106. (Series "Filosofiia svobody", issue II). (In Russ.).

Hayek, F. (1999) Poznanie, konkurentsiia i svoboda [Cognition, competition and freedom] / transl., comp. and foreword by S. Maltseva. St. Petersburg : Pnevma Publ. 287 p. (In Russ.).

Hayek, F. (2003) Liberalizm [Liberalism]. In: Friedman, M. and Hayek, F. O svobode [On freedom]. Chelyabinsk : Sotsium ; Moscow : Tri kvadrata Publ. 182 p. Pp. 129-168. (Series “Filosofiia svobody”, issue II). (In Russ.).

Hayek, F. (2006) Pravo, zakonodatel'stvo i svoboda: sovremennoe ponimanie liberal'nykh printsipov spravedlivosti i politiki [Law, legislation, freedom: A modern understanding of the liberal principles of justice and politics] / transl. from English by B. Pinsker and A. Kustarev ed. by A. Kuriaev. Moscow : IRISEN Publ. 644 p. (In Russ.).

Harvey, D. (2018) Sotsial'naia spravedlivost' i gorod [Social justice and the city] / transl. from English by E. Yu. Gerasimova. Moscow : Novoe literaturnoe obozrenie Publ. 440 p. (In Russ.).

Shamileva, R. K. (2004) Modeli spravedlivosti v sovremennoi liberal'noi teorii Zapada [Models of justice in contemporary Western liberal theory]. Moscow : Maks Press. 260 p. (In Russ.). 
Shamileva, R. K. (2005) Liberal'naia kontseptsiia spravedlivosti: mif ili real'nost'? [Liberal conception of justice: Myth or reality?]. Sotsial'nogumanitarnye znaniia, no. 6, pp. 269-279. (In Russ.).

Strauss, L. (2000) Progress ili vozvrat? Sovremennyi krizis zapadnoi tsivilizatsii [Progress or return? Contemporary crisis in Western civilization]. In: Strauss, L. Vvedenie $v$ politicheskuiu filosofiiu [Introduction to political philosophy] / transl. from English by M. Fetisov. Moscow : Logos Publ. ; Praksis Publ. 364 p. Pp. 264-293. (In Russ.).

MacIntyre, A. (1988) Whose justice? Which rationality? London : Duckworth. xi, $410 \mathrm{p}$.

Nussbaum, M. (1990) Aristotelian social democracy. In: Liberalism and the good / ed. by R. B. Douglass, G. M. Mara, H. S. Richardson. New York : Routledge. viii, 289 p. Pp. 203-252.

Nussbaum, M. C. (1992) Human functioning and social justice: In defense of Aristotelian essentialism. Political Theory, vol. 20, no. 2, pp. 202-246.

Nussbaum, M. C. (2000) Women and human development: The capabilities approach. Cambridge ; New York : Cambridge University Press. xxi, 312 p. (John Robert Seeley lectures).

Nussbaum, M. C. (2005) Beyond the social contract: Capabilities and global justice. In: The political philosophy of cosmopolitanism / ed. by G. Brock, H. Brighouse. Cambridge : Cambridge University Press. x, 262 p. Pp. 196-218.

Rawls, J. (1971) A theory of justice. Cambridge, MA : Belknap Press of Harvard University Press. xv, 607 p.

Rawls, J. (2005) Political liberalism. Expanded edn. New York : Columbia University Press. lx, 525 p.

Young, M. (1961) The rise of the meritocracy. 1870-2033 : An essay on education and equality. Harmondsworth : Penguin Books. 189 p.

Submission date: 10.01.2019.

Канарш Григорий Юрьевич — кандидат политических наук, старший научный сотрудник сектора социальной философии Института философии РАН. Адрес: 109240, г. Москва, ул. Гончарная, д. 12, стр. 1. Тел.: +7 (495) 697-98-93. Эл. адрес: grigkanarsh@yandex.ru

Kanarsh Grigory Yurievich, Candidate of Political Sciences, Senior Researcher, Department of Social Philosophy, Institute of Philosophy, Russian Academy of Sciences. Postal address: 12 Goncharnaya St., Moscow, Russian Federation, 109240. Tel.:+7 (495) 697-98-93. E-mail: grigkanarsh@yandex.ru

\section{Для ичитирования:}

Канарш Г. Ю. Социальная справедливость: современная история идеи [Электронный ресурс] // Горизонты гуманитарного знания. 2019. № 1. С. 4873. URL: http://journals.mosgu.ru/ggz/article/view/951 (дата обращения: дд.мм. гггг). DOI: 10.17805/ggz.2019.1.3 